\title{
Mediation in Light of Modern Identity
}

\author{
Ida Helene Asmussen
}

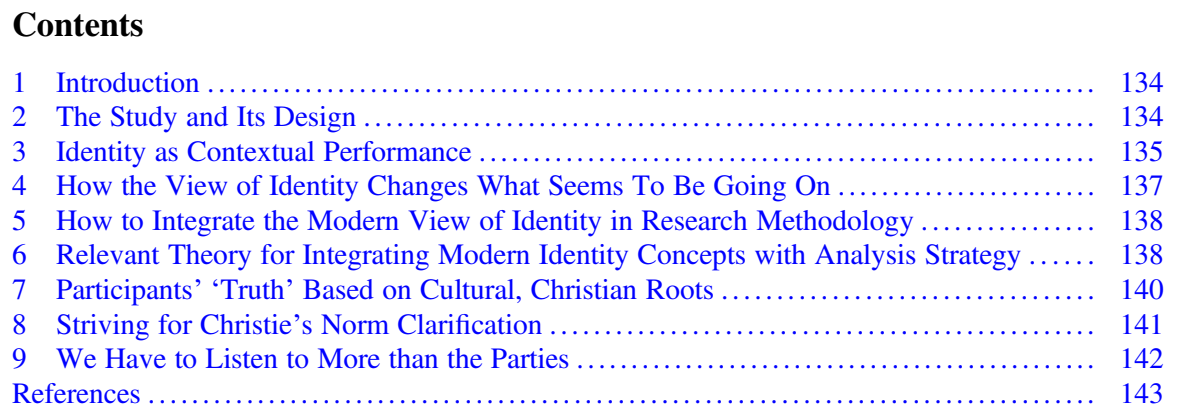

\begin{abstract}
In this contribution, I unfold how adapting a modern identity concept can transform the understanding of mediation. Since the middle of the twentieth century, a new way of understanding identity has developed within sociology and similar scientific fields. Further, within the last 20 years, it has become increasingly recognised that identity is changing and flexible and thus highly context dependent. In the article, I explore how the new identity concept changes the perception of what is going on in mediation. I go on to exemplify the roles that the parties assume. I also provide some central analytical tools of how to approach research analysis when incorporating this understanding of identity. A qualitative study of victim offender mediation (VOM) illustrates my points, but as the points raised here also address the basic premises of the mediation session, the present contribution is indeed also relevant to other fields of mediation research and practice.
\end{abstract}

\footnotetext{
I. H. Asmussen ( $ه)$

Faculty of Law, University of Copenhagen, Copenhagen, Denmark

e-mail: idha@jur.ku.dk
} 


\section{Introduction}

Mediation theory and mediation research is, to a large extent, based on the assumption that what is expressed by the parties are reflections of their truths, needs and interests. ${ }^{1}$ The present contribution to the debate challenges that assumption by showing how a modern social constructivist view on identity changes the analysis of what is going on in mediation. This view of identity changes the dialogue to a matter of presenting a self that fits into a context rather than a matter of expressing authentic needs and interests. The article exemplifies this position by means of the conclusions of a recent study, where this modern view of identity was purposefully used as a theoretical and methodological framework (Asmussen 2014, 2015, 2017). ${ }^{2}$ The study points out a series of participant positions and shows how these positions are structured by our Christian cultural roots. Hereby, the change of identity concept leads to a change of definition of mediation from a session where the parties get a chance to express themselves and solve their conflict to a session where predictable values and logics are reproduced and negotiated.

Before moving into the substance, I will give a short introduction to the study that I refer to throughout the article in order to concretise this issue. Having introduced the study and its empirical context, I will elaborate upon the concept of what I term a modern understanding of identity. In continuation of unfolding the concept, I will give a concrete example from a mediation session that shows how this understanding of identity changes the interpretation of what is going on in mediation. Accordingly, I will reflect on how a different understanding of identity influences research methodology and analysis strategy, describing also how I have integrated this approach in the overall study example. I finally present the results of the study in order to show how research built on a different identity concept substantially changes the results of an observation and interview study of mediation.

\section{The Study and Its Design}

The research that underpins this article takes its point of departure in a qualitative study of mediation in criminal cases. More specifically, the article is based on a series of observations of mediation sessions in Denmark and on interviews with participants.

After 16 years with victim offender mediations (VOM) as pilot projects in a few Danish police districts, offering VOM is now a nationwide possibility in Denmark implemented by a law effective from January 2010 (Lov om konfliktråd 2009). In

\footnotetext{
${ }^{1}$ There are, of course, mediation models based on constructivist social theory, e.g. narrative mediation (Winslade and Monk 2008).

${ }^{2}$ This chapter is based on and combines three earlier publications Asmussen (2014, 2015, 2017).
} 
Denmark, VOM only works as a supplement to standard prosecution and court proceedings and, as a consequence, there are no limits to the kind of criminal offence that may proceed to VOM. There is, however, a minor exception to the separation of VOM and criminal proceedings: in cases where VOM has been pursued and applied, the judge could let an offender's participation in VOM count as a mitigating circumstance when meeting out the sentence.

I carried out the study in three different police districts in Denmark from June through December 2010, representing both urban and rural areas. I observed 12 VOMs, ${ }^{3}$ with a total of 52 participants. ${ }^{4}$ After having observed a VOM session, I conducted interviews with those participants who were willing to participate. I recorded 43 semi-structured interviews either in continuation of the observation of a VOM or within a maximum of 20 days. Moreover, I did follow-up-interviews with offenders and victims 10-12 months later. All the data was subsequently analysed in depth by means of qualitative data processing software (HyperResearch).

As supplementary, empirical support, I observed one VOM and five conferences ${ }^{5}$ in three different VOM districts in Norway and conducted 40 semi-structured interviews with the relevant participants from March through October 2011. In Norway, VOM and other restorative processes can supplement standard prosecution and criminal proceedings in different ways or be a separate alternative to conventional proceedings depending on, among other things, the age of the offender and the kind of criminal offence in question.

\section{Identity as Contextual Performance}

Erving Goffman is one of the central thinkers to critically rethink the idea of identity as a set of characteristics that we all 'carry around'. Goffman's basic notion is that the way we behave and interact depends on the norms and expectations of the context. As the context is continuously changing, so is the self-performance. As Goffman puts it, the moment we enter a context where other people are present, an interpretation process begins regarding the expectations of the context and how to fulfil these expectations (Goffman 1959).

The interpretation revolves around questions such as: 'what kind of performance is expected from me?' Or 'how do I help others succeed with the role they prefer to play?' Thus Goffman presumes that there is a kind of unspoken, social contract of

\footnotetext{
${ }^{3}$ Six cases involved violence, one a threat against a person, three burglaries, one theft, and one a neighbour dispute. This distribution of offences matches the general distribution in Danish VOMs, see Hansen (2012).

${ }^{4}$ The number is due to the fact that several victims participated in one of the cases and I observed (and interviewed) everyone who participated, including supporters and mediators.

${ }^{5}$ In Norwegian, conferences are called stormøter.
} 
individuals helping each other succeed with their performance. This means that one might, for instance, laugh even though one might not find a joke funny; might express interest without being interested; might yawn without being tired, and so on. These responses would typically be expressed in order to help others save face or in order to present oneself as a laughing, engaged or bored (by what is going on) individual. As a consequence of this viewpoint, Goffman understands expressions like these, and interactions as such, as performing a specific self, according to the context rather than being a specific identity.

One of Goffman's examples is a person falling down stairs saying 'oops'. In a Goffman perspective, this is far from a "natural emotional expression" (Goffman 1981) of a person falling. But rather it is a "symbolic gesture ... constitutive of the meaning of the sequence as a whole" (Rawls 1992) and a message from the sender to the people who observed the fall. With this expression it is indicated: 'I am not drunk, clumsy or used to falling. The act of falling is actually kind of surprising to myself.' In continuation of that one could ask whether you would say 'oops' if you were falling in a place where nobody is nearby. It is thus shown that expressions, to a large extent, are about conveying a certain self rather than transparent expressions of a person's inside.

With this contextual view on human expressions and interaction in mind, we have to modify the idea of what is expressed in a mediation session as the 'parties' truths ${ }^{, 6}$ as the situation primarily refers to an idea of authentic and absolute selves, not integrating how the context influences the 'truths'. In more theoretical terms, we have to pay attention to a more socio-constructive way of understanding the participants in mediation. A social constructivist would normally not even use the term 'identity', but might prefer the term 'self-presentation', 'performance' etc. ${ }^{7}$ Social constructivism is a large 'umbrella' and part of this umbrella includes the interactionist view of the self as a product of a social and concrete situation-here presented through Goffman. This implies that the interests and needs that are expressed in a mediation session are first and foremost something that is created in the context-by the institution as such and by the mediator and other participants, including the discourses and narratives they draw on from various other sources and contexts.

Analytically speaking, this approach means that you are not trying to find out what this and that person seems to have on his/her mind, what seems to be important to him/her, what seems not to be important, etc. Rather, you ask what positions, narratives, discourses are created in the situation.

\footnotetext{
${ }^{6}$ For example, Vindeløv (2012).

${ }^{7}$ For more about social constructivism and the theoretical basis, see Asmussen (2017).
} 


\section{How the View of Identity Changes What Seems To Be Going On}

Let me provide an illustrative example (cited in Asmussen 2017) that exemplifies how this new view of identity changes what seems to be going on. The following example is drawn from an observation of a VOM in Denmark. It stems from an exchange between an offender and a series of victims whose houses he had broken into. The exchange is taken from the end of a VOM session:

(1) Heather (victim): "It is very commendable of Ray to participate in this."

(2) Stone (victim): "This has been a positive experience. I hope you get your life together."

(3) Harry (victim): "I am hungry. I can't wait to get home."

(4) Ray (offender): "Thank you for letting me be who I am. I see this meeting as a sign of new times."

(5) Joe (victim), sharply: "All we need now is your apology, Ray."

(6) Ray: "I'm so very sorry."

(7) Heather: "I hope we haven't been too harsh on you."

(8) Joe: "Let's not make things too rosy."

If we approach the dialogue from a hermeneutic or phenomenological view of identity, we would look for the needs and interests that we-with our knowledge about mediation theory-expect the victims to express at the meeting. And we would probably consider Joe's statement (statement 5 above) as a need for an apology. However, if we use an interactionist approach to identity as a contextual performance, we would interpret Joe's statement concerning the apology as not necessarily 'brought to the meeting' but as part of the situation-potentially provoked by the altruistic comments of the other participants. So, from a phenomenological point of view, one might see Joe's request for an apology as an expression of Joe's inner needs whereas the interactionist approach would see Joe's request as an expression that is at least partly a result of the context. In continuation of that perspective one could ask whether Joe would have asked for an apology if the others had expressed anger towards the offender.

It is hard to eliminate the possibility that Joe might not have expressed a 'need' for an apology if the others had behaved differently. Thus the example illustrates how the context is shaping 'Joe's self'. 


\section{How to Integrate the Modern View of Identity in Research Methodology}

As a consequence of the interactionist way of understanding self and interaction as contextually produced, I did not consider the data 'collected', but rather as a product of a specific situation that I myself, as a researcher, was part of. At the same time, one must of course distinguish between observations and interviews. As Dingwall (1997) reminds us: "[...] observation is the most fundamental discipline for the sociologist. In an interview study, we can pick and choose the messages that we hear and that we elicit. In observation, we have no choice but to listen to what the world is telling us" (Dingwall 1997). Though Dingwall has a different epistemological grounding, his point is useful in the sense that observations to a much larger extent involve 'listening to what the world is telling us' - though this way to put it is, of course, rather radical. The interview, on the other hand, is a situation where the respondents retrospectively construct their experiences of the meeting and these constructions would not be produced without my initiative, as opposed to the VOM meetings that would take place whether I was there or not. ${ }^{8}$

In the interview setting I am a co-producer of new strategies and positionsbetween me as a researcher and the respondent. The way I approach and formulate my questions is, in other words, limiting the room for manoeuvre available for the respondent: "To put it simply, one can't be a 'self' by oneself, identities must be accomplished in 'shows' that persuade. . individuals [to] negotiate how they want to be known in the stories they develop collaboratively with their audiences" in the interview situation (Riessman 2016). This way of understanding my own role as a co-producer of the data, especially in the interview situation, was taken into account in the subsequent analysis by continually including my interaction as part of the interpretation of what was said.

Finally, the observation and interview data was merged with document analysis of visitation guidelines, evaluation reports and legal-system negotiations to add more direct data on the organisational and institutional framing of the VOMs and the participants.

\section{Relevant Theory for Integrating Modern Identity Concepts with Analysis Strategy}

As already stated, the present study takes a social constructivist point-of-view based on Goffman, and hence the focus of the research conducted dwells on what was created in face-to-face interaction. Goffman's role theory was supplemented with other theories sharing the same epistemological approach and analytical framing,

\footnotetext{
${ }^{8}$ Highlighting this point, I am inspired by Mik-Meyer (2004).
} 
e.g. Conversation analysis (CA), ${ }^{9}$ positioning theory, ${ }^{10}$ discursive psychology ${ }^{11}$ and Foucault's notions about truth and power. In the following I will briefly explain how I used these frameworks to underpin the analysis in accordance with the modern identity concept.

Grounded in the basic ethno-methodological premise that context is locally and situationally produced and actors accordingly accountable, I combined Goffman's thinking about 'the social self' with symbolic interactionism. ${ }^{12}$ Symbolic interactionism offers a textual and linguistic interpretation of the data and thus CA was useful as a source of inspiration. ${ }^{13}$ What was, one might ask, for instance, expressed when the offender continually talked about himself as a 'criminal' in grammatical past form and the victims continually talked about the offender as a 'criminal' in the grammatical present and future forms?

Positioning theory is likewise a useful tool for clarifying some of Goffman's central concepts: Goffman's 'role' thus becomes 'position', and 'positioning' is consequently used to illustrate that the research object is a simultaneous and mutual action, where one speaker is actively positioning himself and by doing that he is also positioning the other(s) and vice versa. Finally, the concepts of 'position' and 'positioning' help to illustrate that what is 'at play' is always only a small and temporary part of a person's repertoire-the part that is expressed in a certain context.

In order to broaden the analytical approach and to investigate identity mechanisms in a broader context, discursive psychology proved a fruitful inspirational field by opening up questions such as: 'which discourse is this statement drawn from?' Or one could go even further, and ask, pace Foucault, 'which logic/truth telling is structuring the discourses expressed in the mediation sessions?' As I will explain in more detail in the following, I found the VOMs to be structured around a confessional ethos.

\footnotetext{
${ }^{9}$ Conversation Analysis has been inspired by ethno-methodology (Harold Grafinkel) and Goffman's theory of interaction. It was formulated in the late 1960s and early 1970s by Harvey Sacks, Emanuel Schegloff and Gail Jefferson.

${ }^{10}$ Wendy Hollway was the first to use 'positioning' in an analysis of gender and subjectivity from 1984, see Harré and Langenhove (1991). Later, the concept was developed, especially within positioning theory, as formulated, in particular, by Rom Harré, Browyn Davies, Luk Van Langenhove and Fathali Moghaddam.

${ }^{11}$ Discursive Psychology developed in the late 1980s and the most quoted work in this regard is Jonathan Potter and Margaret Wetherell's acknowledged book Discourse and Social Psychology: Beyond Attitudes and Behavior (1987).

${ }^{12}$ Inspired by Stax (2005).

${ }^{13}$ The overall principles as turn-taking, minimal responses, inter subjectivity and use of grammatical time forms was used. For a more precise hands-on description of the tools, see Asmussen (2014).
} 


\section{Participants' 'Truth' Based on Cultural, Christian Roots}

What I found when I analysed the VOM sessions was that perpetrators, in particular, demonstrated the characteristics of the 'ideal sinner': regretting, repenting, showing concern for the victim and assuring the other participants of his/her plans for a non-sinful life. I named this position the exemplary offender because the individuals in question seemed to embrace a position that met the expectations of the mediator and the victim. In line with that, the majority of victims positioned themselves as matching the exemplary offender by demonstrating charity and forgiveness by downplaying the crime and focusing on the rehabilitation of the perpetrator. I named this position the altruistic victim. Against this background, the positions can be seen as a reflection of a certain moral assessment of the situation, structured by a confessional ethos; including the demand for remorse on the part of the perpetrator and the demand for mercy on the part of the victim. Seen through the modern view of identity, this is not mirroring the victims' feelings and needs, but rather how they understand the situation and how the common cultural background is shaping the idea of how one should approach a situation where someone has committed a 'sin' or has been the victim of others' sinful actions.

The conclusions of the study actualise essential parts of Foucault's thinking. Foucault states that the pastor's imperative for confession did not cease with the reduced influence of the church, but continues to function in modern society through the notion of confession as the means of liberation. Foucault has described how the notions of truth and logic of the past are handed down and reproduced in new forms. From the fourth to the sixth century, the task of the pastor changed from ensuring the salvation of the congregation to ensuring that of the individual (Foucault 2000a). The pastor was hence dependent on the individuals allowing him admittance to their inner life of their own accord, i.e. relating their sins. Against that backdrop, the conception was formed that each individual was obliged to confess their sins to God and a series of related practices evolved, including absolution (Foucault 2000a). Seen in this light, mediation is based on the idea of liberation through articulation and externalisation of an inner truth.

Foucault also pinpoints that secular confession is an ongoing theme in modern lifestyle - a catharsis-like willingness to relate one's inside: "one confesses one's crimes, one's sins, one's thoughts and desires, one's illnesses and troubles; one goes about telling, with the greatest precision, whatever is most difficult to tell. One confesses in public and in private, to one's parents, one's educators, one's doctor, to those one loves; one admits to oneself in pleasure and in pain, things it would be impossible to tell to anyone else, the things people write books about. When it is not spontaneous or dictated by some internal imperative, the confession is wrung from a person by violence or threat ...Western man has become a confessing animal" (Foucault 1978). Foucault describes genealogically how the medieval pastoral governance of the Christian confession produced a logic saying that man should be led by the will of relating the truth about one self, and that this truth-telling is still at play in modern society. Today, though not led by the pastor, but by psychologists, 
therapists, pedagogues, coaches etc. (Foucault 2000b). This 'pastoral governance', stimulating man to govern himself through confession, is arguably also a mantra in mediation.

A smaller group of participants, described as the uncompromising victim and the resentful offender, ${ }^{14}$ presented resistance against entering into the roles in the Christian-cultural 'script'. These 'outliers' can be viewed in the light of Foucault's words: "There is no power without revolt" (Foucault 1999). For these participants, the mediation session became a struggle to redefine the situation. An example of this is a mediation session where a resentful offender with some luck redefines the session from a situation where he should be the one to regret a situation to where the victim should express fault and regret. The way this is done is by claiming that the victim-by reporting the criminal episode-is responsible for the judgment of the offender. The case highlighted below was about threats towards a caseworker who had decided that a father, for a given period of time, should be denied access to his children. In line with the notion of positioning, the offender (re)positions the caseworker as someone who was supposed to help him and is thereby especially obliged to show loyalty, as illustrated in the following statement taken from the mediation session:

I only have you Camilla (the caseworker), I haven't got anybody else, and (looking at the mediator) she cannot handle me. (Turning back to Camilla) I have to go back to jail because of you. I was only judged because of you.

\section{Striving for Christie's Norm Clarification}

In cases like the above, played out by the resentful offender and/or the uncompromising victim, the parties were quarrelling about who should take the blame and the responsibility, or they gave up on the dialogue entirely because it was hard to find a basic consensus.

Christie (1977) pinpoints that mediation is a possibility of discussions as communities, i.e. "opportunities for norm-clarification". He expands this point through a description of the losses potentially involved in upholding the conventional legal process:

It is a loss of pedagogical possibilities. It is a loss of opportunities for a continuous discussion of what represents the law of the land. How wrong was the thief, how right was the victim? Lawyers are [...] trained into agreement on what is relevant in a case. But that means that it is difficult to stage what we might call a political debate in court. When the victim is small and the offender big-in size or power-how blameworthy then is the crime?

[...] If the offender is well educated, ought he then suffer more or maybe less, for his sins?.

I do not believe the discussion exemplified above fulfils Christie's hopes for mediation, but at least there was a concrete discussion of morale, guilt, responsibility

\footnotetext{
${ }^{14}$ Moreover, the study includes a description of the therapeutic victim and a pattern among young men named offstage performance. For more about these positions, see Asmussen $(2014,2015)$.
} 
and different positions in society. These discussions were not actualised in the majority of sessions I observed because, as described above, the session positions were played out by the exemplary offender and the altruistic victim, and they agreed on the moral situation and role playing. In other words, if we would encourage discussions of norm-clarification, we have to create awareness of these powerful cultural discourses and narratives that guide us to repetition and reproduction. Whatever we do, we cannot wash the human brain clean of language and history (which would indeed create yet other problems); but that said, being more observant of our automatic ways of positioning others and ourselves could be a way forward towards creating more space for fruitful discussion, including the discussions of norm-clarification that Christie called for.

\section{We Have to Listen to More than the Parties}

Approaching mediation with a modern understanding of identity in mind, it is not enough to carry out research that reveals what is at stake for the parties. The approach will have to be supplemented with research that reveals what is at play in the organisations and institutions surrounding individuals: 'how do the municipal institutions contribute to the actions and expressions of the parties?' 'What narratives, discourses and positions are produced and reproduced in the context?' and so on. Otherwise, we are only uncovering half of what is going on. Being aware of the institutional level and making it visible in the mediation sessions could contribute to the substance of and transparency in mediation practise, just as stakeholders will have to stay open-minded and develop practices in accordance with the mediation models that allow for a modern understanding of identity. ${ }^{15}$

In other words, the modern concept of identity forces us to face Christie's famous words about "giving the conflict back to the parties" (1977)_admittedly a far from simple task. As pinpointed here, what is expressed by the parties in a mediation session is much more than their truths. It remains a challenge to ascertain how to best approach mediation in practise and how to most fruitfully approach mediation research; nevertheless, we scholars would do well to rise to this challenge. In this article, I have hinted that the challenge is surmountable. Working towards making changes to mediation ought to be worthwhile in a wider societal perspective, as adjustments could potentially improve the mediation process and thereby the output for the parties. Finally, viewing mediation through the lens of a modern concept of identity will broaden and extend the body of research in the field in a way that will lead to a more nuanced and comprehensive picture of what is going on in-and not least what is achievable through-mediation now and in future.

\footnotetext{
${ }^{15}$ Narrative mediation could be an example of including the social constructivist view in practice, Winslade (2006).
} 


\section{References}

Asmussen IH (2014) Fra Retsstat til Omsorgsstat—om syndsforladelse i konfliktråd. DJØF, Copenhagen

Asmussen IH (2015) Performing absolution narratives in restorative justice. Restor Justice Int $\mathbf{J} 3$ (1):28-48

Asmussen IH (2017) Old Goffman as a new research strategy in restorative justice. In: Aertsen I, Pali B (eds) Critical restorative justice. Hart, Oxford, pp 143-159

Christie N (1977) Conflicts as property. Br J Criminol 17(1):1-15

Dingwall R (1997) Accounts, interviews and observation. In: Miller G, Dingwall R (eds) Context and method in qualitative research. Sage, London, pp 51-65

Foucault M (1978) The history of sexuality, vol 1. Pantheon, New York

Foucault M (1999) Pastoral power and political reason. In: Carette R (ed) Religion and culture foucault. Routledge, New York, pp 135-152

Foucault M (2000a) Omnes et singulatim: toward a critique of political reason. In: Faubion J (ed) Power. Penguin, Harmondsworth, pp 298-325

Foucault M (2000b) The subject and power. In: Faubion J (ed) Power. Penguin, Harmondsworth, pp 326-348

Goffman E (1959) The presentation of self in everyday life. Anchor Books, New York

Goffman E (1981) Forms of talk. University of Pennsylvania Press, Pennsylvania

Hansen KF (2012) Evaluering af konfliktråd - den landsdækkende ordning. Center for Alternativ Samfundsanalyse (CASA), Copenhagen

Harré R, Langenhove L (1991) Varieties of positioning. J Theory Soc Behav 21(4):393-407

Mik-Meyer N (2004) Dømt til personlig udvikling. Hans Reitzels Forlag, Copenhagen

Potter J, Wetherell M (1987) Discourse and social psychology: beyond attitudes and behavior. SAGE, London

Rawls AW (1992) Order of interaction and intelligibility. In: Trevino AJ (ed) Goffmans legacy. Rowman \& Littlefield, Oxford

Riessman CK (2016) Performing identities in illness narrative: masculinity and multiple sclerosis. Qual Res 3(1):5-33

Stax T (2005) Duetter fra anden sal - et interaktionelt perspektiv på samtaler mellem hjemløse og socialarbejdere. Københavns Universitet, Sociologisk Institut, Copenhagen

Vindel $\varnothing \mathrm{v}$ V (2012) Reflexive mediation with a sustainable perspective. DJØF Publishing, Copenhagen

Winslade J (2006) Mediation with a focus on discursive positioning. Confl Resolut Q 23(4):501-515

Winslade J, Monk G (2008) Practising narrative mediation - loosening the grip of conflict. JosseyBass, San Francisco

Open Access This chapter is licensed under the terms of the Creative Commons Attribution 4.0 International License (http://creativecommons.org/licenses/by/4.0/), which permits use, sharing, adaptation, distribution and reproduction in any medium or format, as long as you give appropriate credit to the original author(s) and the source, provide a link to the Creative Commons license and indicate if changes were made.

The images or other third party material in this chapter are included in the chapter's Creative Commons license, unless indicated otherwise in a credit line to the material. If material is not included in the chapter's Creative Commons license and your intended use is not permitted by statutory regulation or exceeds the permitted use, you will need to obtain permission directly from the copyright holder.

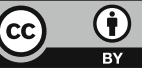

